\title{
ANALISIS PRODUKTIVITAS ALAT BERAT MESIN BOR AUGER, CRAWLER CRANE, DAN EXCAVATOR PADA PROYEK A DAN B
}

\author{
Williem Jaya ${ }^{1}$, Arianti Sutandi ${ }^{2}$ \\ ${ }^{1}$ Program Studi Sarjana Teknik Sipil, Universitas Tarumanagara, Jl.Letjen S. Parman No.1 Jakarta \\ Email: williemjaya8@gmail.com \\ ${ }^{2}$ Program Studi Sarjana Teknik Sipil, Universitas Tarumanagara, Jl.Letjen S. Parman No.1 Jakarta \\ Email: ari.sutandi@gmail.com
}

\begin{abstract}
ABSTRAK
Pemilihan alat berat yang akan digunakan sangat berpengaruh pada kelancaran suatu proyek konstruksi. Alat berat yang digunakan harus tepat sehingga proyek atau pekerjaan dapat berjalan dengan lancar. Penelitian ini dibatasi pada masalah produktivitas pada alat bor auger/ drilling machine, crawler crane dan excavator. Dalam pencarian nilai produktivitas tersebut, penulis juga mencoba menghitung besaran nilai waktu siklus dan efisiensi dari masing- masing alat tersebut. Adapun nilai produktivitas bor auger/ drilling machine pada proyek A adalah sebesar $38,4484 \mathrm{~m}^{3} / \mathrm{hari}$, sedangkan untuk proyek B memiliki nilai sebesar $51,9845 \mathrm{~m}^{3} /$ hari. Nilai produktivitas untuk alat berikutnya yaitu crawler crane adalah 1371,2083 ton/hari pada proyek A dan 3969,3276 ton/hari pada proyek B. Pada alat terakhir yaitu excavator, diperoleh besaran produktivitas sebesar 138,4112 $\mathrm{m}^{3} /$ hari pada proyek A dan $462,6257 \mathrm{~m}^{3} /$ hari pada proyek B.
\end{abstract}

Kata kunci: waktu siklus, efisiensi, produktivitas, alat- alat berat

\section{PENDAHULUAN}

\section{Latar belakang}

Alat berat merupakan alat yang digunakan untuk membantu manusia dalam pekerjaan konstruksi. Penggunaan alat berat pada konstruksi bangunan bertujuan untuk mempermudah dan mempercepat proses pekerjaan konstruksi, sehingga pemilihan dan penggunaan alat- alat berat memegang peranan yang sangat penting dan harus dilakukan dengan tepat agar keberhasilan proyek dapat tercapai. Namun pada pelaksanaanya, terkadang penggunaan alat- alat berat dalam suatu proyek kurang baik. Hal ini dikarenakan kapasitas, jumlah alat yang tidak sesuai dengan kondisi lapangan dan volume pekerjaan yang akan dikerjakan. Penggunaan alat berat yang kurang tepat dengan kondisi dan situasi lapangan pekerjaan akan berpengaruh pada rendahnya produktivitas alat dan tidak tercapainya jadwal atau target yang telah ditentukan. Selain itu semakin lama pengunanan alat yang digunakan semakin besar juga biaya yang harus dikeluarkan untuk proyek tersebut.

Pada penelitian ini akan dianalisis produktivitas alat- alat berat berupa mesin bor auger/ Drilling Machine, Crawler Crane, dan Excavator yang digunakan pada pekerjaan pondasi bore pile di proyek bangunan tinggi. Dalam penelitian ini akan ditinjau waktu siklus efisiensi dan produktivitas setiap alat berat tersebut, kemudian akan dianalisis untuk mendapatkan jumlah penggunaan alat- alat berat yang paling baik.

\section{Maksud dan tujuan penelitian}

Maksud penulisan ini adalah untuk mengetahui waktu siklus, efisiensi kerja dan produktivitas masing- masing alat berat serta mengetahui jumlah alat pada proses pekerjaan pondasi bore pile proyek A dan proyek B. Sedangkan tujuan penulisan ini adalah untuk membandingkan waktu siklus, efisiensi dan produktivitas dari 3 alat berat yang digunakan dalam pekerjaan pondasi pada dua proyek yang berbeda serta menilai kesesuaian jumlah alat yang digunakan pada proyek tersebut dengan kebutuhannya.

\section{Batasan penelitian}

Batasan masalah penelitian ini adalah proyek yang ditinjau adalah proyek pembangunan gedung bertingkat di proyek A dan proyek B, alat berat yang ditinjau adalah Bor Auger/ Drilling Machine, Crawler Crane, dan Excavator, pekerjaan yang ditinjau adalah pekerjaan pengeboran, pekerjaan pemasangan tulangan besi, pekerjaan pemasangan pipa tremi dan pekerjaan pemindahan tanah. 


\section{DASAR TEORI}

\section{Alat- alat berat}

Menurut Soedrajat (1982), alat berat yang digunakan dalam ilmu teknik sipil adalah alat yang digunakan untuk membantu manusia dalam melakukan pekerjaan pembangunan suatu struktur. Peralatan atau alat berat dalam pekerjaan sipil banyak berkaitan dengan pemindahan tanah (earth moving) dan segala aspek yang timbul dari peralatan yang digunakan untuk memindahkan tanah tersebut.

Dalam hal pemindahan tanah ini selain memindahkan juga mengadakan pembentukan terhadap permukaan tanah yang baru sesuai kondisi fisik/teknis yang diinginkan. Diperlukan beberapa jenis peralatan dan metode yang sesuai untuk pembentukan permukaan tanah pada lokasi baru tersebut. Karena pekerjaan ini berhubungan dengan tanah, batuan, vegetasi (pohon, semak belukar dan alang-alang) maka perlu diketahui sifat tanah dan tipe galian tanah.

Sifat fisik yang harus dihadapi alat berat akan berpengaruh dalam :

1. Menentukan jenis alat dan taksiran atau kapasitas produksi.

2. Perhitungan volume pekerjaan.

3. Kemampuan kerja alat pada kondisi material yang ada.

Apabila pemilihan jenis alat berat tidak sesuai dengan kondisi material dapat berakibat tidak efisiennya alat (lost time).

\section{Proyek konstruksi}

Proyek adalah suatu kegiatan yang mempunyai jangka waktu tertentu dengan alokasi sumber daya terbatas, untuk melaksanakan suatu tugas yang telah digariskan. Menurut Cleland dan King (1987), proyek adalah gabungan dari berbagai sumber daya, yang dihimpun dalam suatu wadah organisasi sementara untuk mencapai suatu sasaran tertentu.

\section{Manajemen alat berat}

Menurut Wilopo (2011), manajemen pemilihan dan pengendalian alat berat adalah proses merencanakan, mengorganisir, memimpin dan mengendalikan alat berat untuk mencapai tujuan pekerjaan yang ditentukan.

\section{Jenis- jenis alat berat untuk pekerjaan konstruksi bore pile}

Alat- alat yang umumnya digunakan untuk pekerjaan konstruksi bore pile adalah Bor Auger/ Drilling Machine, Crawler Crane, Excavator dan Dumptruck.

\section{Bor auger / drilling machine}

Menurut Jimeno (1995), Bore Machine merupakan suatu alat berat yang digunakan untuk mengangkat material secara vertikal dan digunakan untuk proses pengeboran pondasi bored pile perpaduan antara crane dengan alat bor. Disebut bore karena memiliki fungsi sebagai alat bor pada pondasi bored pile. Fungsi utama dari bore machine adalah membuat tiang bor atau pondasi bore pile dan melakukan proses pengecoran pondasi sehingga tertutup kembali. Bore Machine merupakan peralatan alat berat yang digerakkan mesin atau motor.

\section{Crawler crane}

Menurut Rostiyanti (2008), Crawler Crane merupakan salah satu jenis alat berat alternatif pengganti tower crane apabila dalam sebuah proyek memerlukan alat berat yang mencakup ketinggian dengan mobilitas yang tinggi, dan bisa juga digunakan pada pembangunan seperti jembatan, jalan, bendungan dan pekerjaan pembangunan lainnya.

\section{Excavator}

Menurut Rostiyanti (2008), Ekskavator atau excavator (Mesin pengeruk) adalah salah satu alat berat yang terdiri dari mesin di atas roda khusus yang dilengkapi dengan lengan (arm), alat pengeruk (bucket), keranjang dan rumah rumah dalam sebuah wahana putar dan digunakan untuk penggalian (akskavasi). Biasanya digunakan untuk menyelesaikan pekerjaan berat berupa penggalian tanah yang tidak bisa dilakukan secara langsung oleh tangan manusia. Pengertian ini didasarkan dari asal-usul excavator yang diciptakan sebagai alat penggali tanah untuk membangun rel kereta api, serta dari kata "excavation" yang berasal dari bahasa Inggris yang berarti "pengggalian" atau mesin penggali. 


\section{Dumptruck}

Menurut Rochmanhadi (1982), dump truck merupakan suatu alat yang berfungsi memindahkan suatu material dari suatu tempat ke tempat lain. Material yang dipindahkan seperti tanah, pasir, batu split, dan juga material olahan seperti beton kering pada proyek konstruksi.

\section{Waktu siklus}

Menurut Rostiyanti (2008), waktu siklus adalah waktu yang dibutuhkan alat berat untuk melaksanakan satu siklus operasi. Setiap alat mempunyai cara tertentu untuk menghitung waktu siklus tergantung dari cari pengoperasian masing-masing alat.

\section{Efisiensi kerja alat}

Menurut Rostiyanti (2008), efisiensi didefinisikan sebagai besar presentasi kerja alat efektif dibandingkan dengan waktu kerja keseluruhan, misalnya beberapa menit efektifnya beroperasi alat tersebut dalam waktu satu jam kerja. Ada beberapa cara untuk menghitung efisiensi kerja, diantaranya:

1. Work Sampling

2. Five Minute Rating

\section{Work sampling}

Pengukuran produktivitas tenaga kerja sulit dilakukan secara akurat, memerlukan tenaga dan biaya yang besar (Olomolaiye et al, 1998). Untuk mencapai nilai produktivitas yang diharapkan, perencanaan durasi harus dilakukan dengan mempertimbangkan jumlah kelompok kerja yang ada sehingga perencanaan yang dihasilkan dapat sesuai dengan kemampuan tenaga kerja yang ada. Seperti yang sudah dibahas di atas bahwa pengukuran produktivitas tenaga kerja sulit dilakukan secara akurat karena sifat dasar dari pekerja tidak stabil dalam pelaksanaan konstruksi (Olomolaiye et al, 1998), maka pengukuran produktivitas tenaga kerja dilakukan dengan cara pendekatan, yaitu dengan metode work sampling. Work sampling atau yang biasa juga dikenal dengan activity sampling merupakan suatu teknik pengukuran dan analisis produktivitas dengan mengaplikasikan prinsip-prinsip statistik, baik untuk segala aktivitas yang efektif maupun tidak, dengan cara mengambil sampel secara acak (namun harus dapat mewakili seluruh populasi yang ada) dan kemudian menganalisisnya secara lebih lanjut (Pilcher, 1992).

\section{Five minute rating}

Teknik mengumpulkan data dengan cara mengamati aktivitas kerja yang efektif dari kru yang bekerja di masingmasing percobaan di lapangan untuk mendapatkan efektivitasnya sebagaimana dijelaskan oleh Oglesby et al. (1989). Pemilihan waktu acak yang dihasilkan oleh Excel dengan cara mengamati kru yang bekerja. Kemudian, efektif pekerjaan untuk kru yang bekerja selama lima menit diamati setiap percobaan di lapangan.

\section{Produktivitas alat}

Menurut Rostiyanti (2008), produktivitas adalah perbandingan antara hasil yang dicapai (output) dengan seluruh sumber daya yang digunakan (input). Produktivitas alat tergantung pada kapasitas dan waktu siklus alat. Produktivitas alat tergantung pada kapasitas dan waktu siklus alat. Rumus dasar untuk mencari produktivitas adalah:

$$
\text { Produktivitas }=\frac{\text { kapasitas }}{C T}
$$

Umumnya waktu siklus alat ditetapkan dalam menit sedangkan produktivitas alat dihitung dalam produksi/jam sehingga perlu ada perubahan dari menit ke jam. Jika faktor efisiensi alat dimasukkan maka rumus di atas menjadi:

$$
\text { Produktivitas }=\text { kapasitas } x \frac{60}{C T} \times \text { efisiensi }
$$

\section{METODOLOGI PENELITIAN}

\section{Menghitung produktivitas alat berat berdasarkan literatur terdahulu}

Studi literatur adalah serangkaian cara atau kegiatan yang dilakukan peneliti untuk mencari referensi teori yang berkaitan dengan topik atau permasalahan yang akan diteliti. Dalam penelitian ini, digunakan teknik studi literatur untuk mencari produktvitas alat- alat berat pada proyek konstruksi. Studi literatur ini sendiri dilakukan dari berbagai jurnal. Setelah dilakukan studi literatur terhadap jurnal alat- alat berat, peneliti melakukan identifikasi jenis- jenis 
alat berat. Dalam hal ini, dicari waktu siklus, efisiensi dan produktivitas alat berat serta jumlah alat berat pada proyek di lapangan. Kemudian, dilakukan kembali identifikasi literatur untuk mendapatkan produktivitas alat- alat berat tersebut.

\section{Persiapan awal}

Tahapan awal untuk memulai studi penelitian ini adalah dengan melakukan studi pustaka untuk mencari semua informasi yang ada mengenai pekerjaan pondasi bore pile. Studi pustaka yang dilakukan meliputi definisi alat- alat berat, kegunaan alat berat, waktu siklus, efisiensi kerja, dan produktivitas alat berat. Setelah itu dilakukan proses pengumpulan data. Pengumpulan data dilakukan dengan observasi di lapangan. Kemudian dilanjutkan dengan menghitung lalu menganalisis data yang didapat sesuai dengan tujuan studi penelitian ini, yakni ingin mengetahui produktivitas alat berat. Data- data lapangan yang diperlukan agar tujuan studi penelitian mengenai pekerjaan pondasi bore pile bisa terlaksana dengan lancar antara lain: gambar denah pondasi bore pile, data mengenai pengamatan masing- masing alat berat, hasil observasi di lapangan.

\section{Pengumpulan data}

Untuk proses pengumpulan data dilakukan dengan cara menghubungi Owner dan menanyakan tentang pekerjaan pondasi bore pile. Lalu observasi ke lapangan untuk mengamati pekerjaan pondasi bore pile tersebut. Tentunya sebelum ke proyek harus membuat dan menyerahkan surat ijin untuk meminta data dari proyek. Proyek yang ditinjau tidak boleh dipublikasikan.

\section{Observasi di lapangan \& survei lapangan}

Setelah membuat surat ijin survei proyek dan menghubungi owner, langkah berikutnya adalah mengunjungi proyek untuk mendapatkan data- data dengan cara melakukan observasi di lapangan. Kemudian, melakukan survei dengan menanyakan beberapa hal kepada penanggung jawab proyek.

Setelah observasi dan survei di lapangan diketahui alat- alat berat apa saja yang digunakan untuk pekerjaan pondasi bore pile. Alat- alat berat yang digunakan dalam pekerjaan pondasi bore pile antara lain:

1. Pengeboran; Alat- alat berat yang digunakan adalah Mesin Bor Auger/ Drilling Machine.

2. Pemasangan tulangan bore pile; Alat- alat berat yang digunakan adalah Crawler Crane

3. Pemasangan pipa tremi; Alat- alat berat yang digunakan adalah Crawler Crane

4. Pemindahan Tanah; Alat- alat berat yang digunakan adalah Excavator.

\section{Perhitungan dan analisis data}

Setelah melakukan pengumpulan data dengan mengunjungi proyek tempat dilakukannya pekerjaan pondasi bore pile yang bersangkutan, maka data yang didapat harus terlebih dahulu dihitung dan dilakukan analisis berdasarkan rumus- rumus yang telah ada. Sehingga bisa mengetahui waktu siklus, efisiensi kerja dan produktivitas alat berat.

\section{ANALISIS DAN PEMBAHASAN}

Setelah melalui proses pengamatan dan perhitungan yang cukup panjang untuk menemukan jumlah alat yang tepat untuk masing- masing proyek, dalam subbab ini akan dibahas lebih lanjut untuk perbandingan waktu siklus, produktivitas, dan juga penulis akan mencoba untuk melakukan penentuan jumlah alat akhir pada masing- masing proyek.

\section{Analisis waktu siklus}

Hasil perhitungan waktu siklus alat- alat berat yang ditinjau dapat dilihat pada tabel 1.

Tabel 1 Waktu Siklus

\begin{tabular}{cll}
\hline Jenis Alat & Proyek A & Proyek B \\
\hline Bor Auger & 3,4502 menit & 3,0462 menit \\
\hline Crawler Crane & 5,0175 menit & 5,4717 menit \\
\hline Excavator & 0,3333 menit & $0,4 \quad$ menit \\
\hline
\end{tabular}




\section{Waktu siklus bor auger/ drilling machine}

Dari tabel di atas, bisa terlihat bahwa besaran waktu siklus Bor Auger/ Drilling Machine untuk proyek B (3,0462 menit) lebih cepat daripada waktu siklus untuk proyek A (3,4502 menit). Hal tersebut disebabkan karena kedalaman pengeboran yang dilakukan di proyek A lebih dalam yaitu sedalam 51,7 meter dibandingkan dengan B yang hanya mencapai kedalaman 45,3 meter. Dengan lebih dalamnya kedalaman pengeboran, diperlukan waktu lebih lama untuk siklus pengangkatan bucket dari dalam lubang pengeboran. Selain itu ada perbedaan jenis Bor Auger/ Drilling Machine yang digunakan di kedua proyek. Proyek A menggunakan Bor Auger/ Drilling Machine tipe Soilmec RT3ST (tipe lama \pm tahun 70an), sedangkan Bor Auger/ Drilling Machine yang digunakan proyek B adalah tipe Soilmec SR 40 keluaran tahun 2011.

\section{Waktu siklus crawler crane}

Dari tabel 1 terlihat bahwa rata- rata waktu siklus Crawler Crane di A adalah 5,0175 menit, sedangkan pada proyek B adalah 5,4717 menit. Jika ditinjau lebih jauh waktu siklus Crawler Crane terdiri dari 6 pekerjaan dengan rata- rata waktu siklus yang berbeda.

Tabel 2 Waktu Siklus rata- rata untuk setiap pekerjaan

\begin{tabular}{ccc}
\hline Pekerjaan & Proyek A & Proyek B \\
\hline Pengangkatan cashing & 7 menit & 9,5871 menit \\
\hline $\begin{array}{c}\text { Pengangkatan tulangan, } \\
\text { penyambungan tulangan } \\
\text { dengan cara di las }\end{array}$ & 5,4067 menit & 5,6 menit \\
\hline Pengangkatan pipa tremi & 5,7333 menit & 5,3953 menit \\
\hline Pengangkatan corong cor & 3 menit & 3 menit \\
\hline Pelepasan pipa tremi & 5 menit & 3,8571 menit \\
\hline Pelepasan cashing & 8,7 menit & 8 menit \\
\hline
\end{tabular}

Perbedaan waktu yang paling berpengaruh terhadap rata- rata waktu siklus keseluruhan adalah pekerjaan mengangkat cashing. Hal itu dikarenakan luas proyek yang berbeda. Luas proyek di A adalah $\pm 12.066 \mathrm{~m}^{2}$, sedangkan proyek B adalah $\pm 2540 \mathrm{~m}^{2}$, sehingga lahan untuk meletakkan cashing di proyek B sangat terbatas dan Crawler Crane perlu bermanuver lebih jauh untuk meletakkan cashing. Di proyek A tidak perlu manuver jauh karena cashing diletakkan dekat Crawler Crane.

\section{Waktu siklus excavator}

Hal ini terjadi karena di proyek A Excavator baru beroperasi setelah pengecoran selesai sehingga Excavator tidak bertabrakan dengan Bor Auger/ Drilling Machine maupun Crawler Crane hal ini dimungkinkan karena lokasi proyek yang lebih luas. Sedangkan di proyek B, Excavator harus mengangkat tanah saat Bor Auger/ Drilling Machine masih bekerja karena lahan yang tidak cukup luas, sehingga manuvernya lebih lama karena lokasi yang lebih jauh.

\section{Analisis produktivitas alat berat}

Hasil perhitungan produktivitas alat- alat berat yang ditinjau dapat dilihat pada tabel 3.

Tabel 3 Produktivitas Alat Berat

\begin{tabular}{ccc}
\hline Jenis Alat & Proyek A & Proyek B \\
\hline Bor Auger & $38,4484 \mathrm{~m}^{3} /$ hari & $51,9845 \mathrm{~m}^{3} /$ hari \\
\hline Crawler Crane & 1371,2083 ton/hari & 3969,3276 ton/hari \\
\hline Excavator & $138,4112 \mathrm{~m}^{3} /$ hari & $462,6257 \mathrm{~m}^{3} /$ hari \\
\hline
\end{tabular}

\section{Produktivitas bor auger/drilling machine}

Dari tabel di atas, terlihat bahwa nilai produktivitas Bor Auger/ Drilling Machine di proyek B yaitu $51,9845 \mathrm{~m}^{3} / \mathrm{hari}^{2}$ lebih besar daripada nilai produktivitas Bor Auger/ Drilling Machine di proyek A yaitu sebesar 38,4484 $\mathrm{m}^{3} / \mathrm{hari}$. Berdasarkan hasil tersebut, perbedaan produktivitas dari kedua alat di proyek berbeda tersebut cukup besar hingga mencapai 35,21\%. Menurut pengamatan di lapangan, perbedaan yang cukup signifikan untuk alat tersebut disebabkan oleh beberapa hal. Hal yang paling terlihat mencolok bagi penulis adalah spesifikasi mesin yang digunakan. Apabila di proyek A hanya menggunakan kapasitas pengeboran dengan kedalaman maksimal 60 meter, 
di proyek B menggunakan kapasitas pengeboran dengan kedalaman maksimal 120 meter. Hal tersebut mengakibatkan tingkat kemudahan penggunaan alat Bor Auger/ Drilling Machine di proyek B jauh lebih baik dengan volume yang lebih. Dengan demikian, apabila volume pengeboran semakin besar, semakin besar juga untuk tingkat produktivitas dari alat tersebut.

Selain faktor dari kapasitas alat, faktor lain yang cukup berpengaruh terhadap produktivitas Bor Auger/ Drilling Machine di lapangan adalah jumlah alat yang tersedia di lapangan. Di proyek B yang memiliki nilai produktivitas lebih besar, hanya digunakan 1 alat Bor Auger/ Drilling Machine. Hal tersebut cukup berbeda dengan adanya 3 unit alat Bor Auger/ Drilling Machine di proyek A. 1 alat Bor Auger/ Drilling Machine yang ada di proyek B memiliki tanggung jawab dan kewajiban penyelesaian pekerjaan yang lebih tinggi. Hal tersebut dikarenakan apabila 1 unit Bor Auger/ Drilling Machine tersebut tidak bekerja secara cepat dan memiliki produktivitas yang tinggi, pekerjaan keseluruhan dari pengeboran di proyek B dapat terhambat. Hal demikian tidak ada di proyek A. Di proyek tersebut, terdapat 3 unit alat Bor Auger/ Drilling Machine yang membuat mesin tersebut ketiganya dapat membagi pekerjaan dan sama rata. Menurut perhitungan penulis di atas, jumlah Bor Auger/ Drilling Machine di proyek A adalah sebanyak 2,73 unit. Hal tersebut menunjukkan bahwa terdapat ruang sebesar 0,27 dari pekerjaan yang menyebabkan seluruh alat berat tersebut tidak perlu bekerja terlalu keras dalam penyelesaian proyek. Selain hal tersebut, faktor psikologis (tenang karena ada Bor Auger/ Drilling Machine lain yang bekerja) cukup membuat tingkat kepercayaan diri pekerja/ operator cukup tinggi sehingga sangat memungkinkan bagi mereka untuk menyepelekan pekerjaan mereka.

\section{Produktivitas crawler crane}

Penggunaan Crawler Crane di proyek B memiliki tingkat produktivitas yang lebih tinggi dibandingkan proyek A (3969,3276 ton/hari banding 1371,2083 ton/hari). Apabila keduanya dibandingkan, maka akan muncul selisih perbedaan kedua alat sebesar $189,48 \%$. Hal tersebut sangat masuk akal karena ada beberapa mayor yang menyebabkan perbedaan yang cukup signifikan. Nilai pemasangan yang dilakukan oleh Crawler Crane di proyek A cukup rendah akibat rendahnya hasil pekerjaan yang dihasilkan dari penggunaan Bor Auger/ Drilling Machine. Berbeda dengan proyek B yang hanya memiliki hasil volume pengeboran lebih tinggi (akibat produktivitas Bor Auger/ Drilling Machine) yang lebih tinggi sehingga membuat "pekerjaan" untuk Crawler Crane cukup banyak dan harus diselesaikan dalam waktu singkat agar tidak muncul pekerjaan yang tertunda.

Di samping hasil pengeboran yang lebih besar, faktor lain yang sangat berpengaruh tentu saja adalah kapasitas dari mesin yang digunakan. Mesin yang digunakan di proyek B memiliki daya hingga mencapai 75 ton. Berbeda dengan proyek A yang hanya memiliki kapasitas 50 ton. Apabila diperhitungkan selisih di antara keduanya, terdapat perbedaan kapasitas hingga $50 \%$ yang membuat hasil pekerjaan di proyek B jauh lebih banyak dibandingkan proyek A.

Selain faktor kapasitas dan hasil pengeboran yang lebih kecil, faktor psikologis yaitu digunakannya 2 alat membuat proyek A cukup lebih santai dalam pengerjaan proyek sehingga mereka akan cenderung lebih lambat. Berbeda dengan proyek B yang hanya menggunakan 1 Crawler Crane, mereka memiliki kewajiban untuk menyelesaikan pekerjaan dengan lebih cepat dan baik karena mereka adalah tulang punggung dari proyek tersebut. Apabila mereka tidak menyelesaikan pekerjaan tepat waktu atau sesuai target yang ditentukan, maka keseluruhan jadwal proyek akan terganggu dan merugikan Kontraktor.

\section{Produktivitas excavator}

Pada proyek B nilai produktivitas dari alat tersebut mencapai angka 462,6257 $\mathrm{m}^{3} /$ hari. Hal tersebut berbanding terbalik dengan produktivitas Excavator yang ada di proyek A yang hanya mencapai angka $138,4112 \mathrm{~m}^{3} / \mathrm{hari}$. Perbedaan dari keduanya mencapai pada angka 234,24\%. Hal tersebut dipengaruhi oleh faktor hasil pengeboran alat yang cenderung lebih sedikit pada proyek A.

Hasil pengeboran di proyek A yang cenderung lebih kecil membuat penggunaan Excavator tidak semaksimal yang ada di proyek B. Semakin besar hasil dari pengeboran, semakin banyak pula material yang perlu dipindahkan oleh Excavator tersebut. Apabila jumlah material yang ada sedikit, pekerja pun pada akhirnya akan cenderung lebih lambat dalam pengerjaannya karena pekerjaan mereka akan selesai terlalu cepat. Guna mencegah hal tersebut, diturunkanlah kecepatan dari pemindahan oleh Operator Excavator di proyek A. 


\section{Analisis jumlah alat}

Hasil perhitungan jumlah alat- alat berat yang ditinjau dapat dilihat pada tabel 4.

Tabel 4 Hasil Perhitungan Jumlah Alat Berat

\begin{tabular}{ccccc}
\hline \multirow{2}{*}{ Jenis Alat } & \multicolumn{2}{c}{ Proyek A } & \multicolumn{2}{c}{ Proyek B } \\
\cline { 2 - 5 } & $\begin{array}{c}\text { Hasil } \\
\text { Perhitungan }\end{array}$ & $\begin{array}{c}\text { Hasil yang } \\
\text { disarankan }\end{array}$ & $\begin{array}{c}\text { Hasil } \\
\text { Perhitungan }\end{array}$ & $\begin{array}{c}\text { Hasil yang } \\
\text { disarankan }\end{array}$ \\
\hline $\begin{array}{c}\text { Bor Auger/ Drilling } \\
\text { Machine }\end{array}$ & 2,73 & 3 & 0,56 & 1 \\
\hline Excavator & 0,29 & 1 & 0,14 & 1 \\
\hline
\end{tabular}

\section{Jumlah bor auger/drilling machine proyek A}

Jumlah penggunaan Bor Auger/ Drilling Machine yang disarankan untuk proyek A adalah sebanyak 3 unit. Jumlah 3 unit tersebut sangat disarankan mengingat jumlah kebutuhan dari Bor Auger/ Drilling Machine itu sendiri mencapai angka 2,73 unit. Apabila jumlah tersebut diturunkan menjadi 2 unit untuk mengejar pengurangan biaya alat, maka pekerjaan tersebut akan tertunda untuk penyelesaiannya. Dengan penggunaan sebanyak 3 alat, maka pekerjaan tersebut akan selesai lebih cepat daripada target waktu penyelesaian sehingga tidak merugikan baik pihak Owner maupun Kontraktor. Berdasarkan pengamatan di lapangan, jumlah Bor Auger/ Drilling Machine yang digunakan di lapangan adalah sebanyak 3 unit. Jumlah tersebut sesuai dengan perhitungan dalam penelitian ini.

\section{Jumlah excavator proyek A}

Penggunaan Excavator di proyek A diperoleh hasilnya sebanyak 0,29 unit. Dapat dipastikan bahwa penggunaan Excavator yang disarankan oleh penulis adalah sebanyak 1 unit. Hal tersebut mengingat sangat tidak mungkin apabila Excavator sama sekali tidak digunakan dalam proyek tersebut. Dalam pelaksanaanya, Kontraktor sudah menggunakan 1 unit Excavator dan hasil tersebut sesuai dengan hasil perhitungan dan analisis penulis.

\section{Jumlah bor auger/drilling machine proyek B}

Berdasarkan tabel di atas, penulis merekomendasi penggunaan Bor Auger/ Drilling Machine sebanyak 1 unit. Hal tersebut mengingat bahwa kebutuhan alat hasil perhitungan hanya 0,56 dan tidak mungkin Bor Auger/ Drilling Machine tidak digunakan sama sekali. Dari hasil pengamatan di lapangan, jumlah Bor Auger yang digunakan oleh Kontraktor sudah sesuai yaitu sebanyak 1 unit.

\section{Jumlah excavator proyek B}

Hal yang sama juga berlaku untuk penggunaan jumlah Excavator di proyek B. Jumlah kebutuhan yang sangat rendah yaitu 0,14, menunjukkan bahwa jumlah minimal dari Excavator yang digunakan adalah sebanyak 1 unit alat. Berdasarkan pengamatan penulis, jumlah tersebut juga sesuai dengan penggunaan alat di lapangan yaitu sebanyak 1 unit Excavator.

\section{KESIMPULAN}

Berdasarkan hasil penelitian studi analisis produktivitas alat berat mesin Bor Auger/ Drilling Machine, Crawler Crane dan Excavator pada proyek A dan B, maka dapat disimpulkan sebagai berikut:

1. Waktu siklus rata- rata Crawler Crane di Proyek B lebih lama dibandingkan dengan Proyek A karena kondisi lapangan yang lebih sempit. Hal tersebut mengakibatkan Crawler Crane Proyek B memerlukan waktu selama 9,5871 menit untuk bermanuver meletakkan cashing sedangkan pada Proyek A hanya memakan waktu selama 7 menit.

2. Waktu siklus dari Excavator sangat dipengaruhi oleh peralatan lain yang berada di sekitarnya dan mengganggu dari pekerjaan alat tersebut.

3. Efisiensi dari ketiga alat yang digunakan di Proyek A lebih rendah dibandingkan dengan efisiensi alat pada Proyek B dikarenakan jam kerja pengecoran Proyek A dibatasi oleh warga sekitar sehingga efisiensi dari alat yang digunakan menjadi lebih rendah.

4. Produktivitas ketiga alat berat yang ditinjau di proyek B lebih besar daripada proyek A karena; perbedaan kapasitas alat dan kondisi lapangan. 


\section{DAFTAR PUSTAKA}

D.I Cleland dan W.R. King 1987. "Proyek Konstruksi”. 18 Maret 2018. www.ilmutekniksipil.com/pengelolaan-danpengendalian-proyek/proyek-konstruksi

Jimeno, C.L. 1995. Drilling and Blasting of Rocks. Rotterdam. Brookfield.

Oglesby, C. H., Parker H.W. and Howell G.A. (1989). Productivity Improvement in Construction, McGraw-Hill

Olomolaiye, P.O., Jayawardane, A.K.W. and Harris, F.C. (1998). Construction Productivity Management, McGrawHill, Inc, Singapore.

Pilcher, R. (1992). Principles of Contruction Management $3^{\text {rd }}$ ed, McGraw-Hill, Inc, Singapore.

Rochmanhadi, 1982, Alat-alat Berat dan Penggunaannya, Departemen Pekerjaan Umum, Jakarta.

Rostiyanti, Fatena, Susi. 2008. Alat Berat Untuk Proyek Konstruksi, Edisi 2. Rineka Cipta, Jakarta.

Soedrajat, 1982, Efisiensi Penggunaan Alat Berat Pada Pengaspalan Jalan Raya, Nova, Jakarta

Wilopo, Djoko., Metode Konstruksi dan Alat-alat Berat, Penerbit Universitas Indonesia, Jakarta, 2009.

Wilopo, Djoko., Metode Konstruksi dan Alat-alat Berat, Fakultas Teknik Universitas Indonesia, Jakarta, 2011. 